УДК 316.728

DOI https://doi.org/10.32840/2707-9147.2020.85.3

К. О. СКЛЯРЕНКО

\title{
ЖИТТЕВИЙ СВІТ СУЧАСНОЇ МОЛОДІ В АКТУАЛЬНИХ УКРАЇНСЬКИХ РЕАЛІЯХ
}

У статті розглядаються особливості інтерпретацій життєвого світу на прикладі досліджень сучасної української молоді. Висувається теза про наявність постмодерністських тендениій в ї̈ орієнтачіях. Ми можемо зафіксувати загальні тенденції, які свідчать про те, що молоде покоління не вважає професійний успіх головним пріоритетом у житті. Взаємовідносини із сім'єю, коханою людиною, сексуальна сфера та спілкування із друзями позитивно очінюються молоддю. "Сім'я», «друзі», «любов», «здоров'я»-яскраві домінуючі ијнності иіннісних пріоритетів наших респондентів. Потім називаються цінності професійної та особистої самореалізації та матеріального добробуту. Сучасна молодь розглядає віртуальний світ як реальний, де активно спілкуються, знайомляться, отримують нову інформацію, заробляють гроші.

В умовах соиіокультурної трансформачії українського суспільства макросочіальні структури втрачають своє значення в повсякденному житті. Тому субкультурна діяльність та міжособистісні контакти поширюються серед сучасної молоді. Існує також орієнтачія на соціальну пасивність та неактивну участь у громадському та громадському житті.

Нові реалії диктують приниип індивідуального виживання, самореалізації, щчо стає основою нової нормативної системи. В Україні лише родичі, друзі та близькі знайомі виступають «сочіальним капіталом» для молоді. Молодь байдужа до молодіжних організачій та асочіачій. Це свідчить про «приватизацію» життя, нехтування соціальними проблемами, неможливість висловити себе та свої потреби конструктивними способами.

На основі даних емпіричного дослідження робиться висновок про те, щуо життєвий світ сучасної украӥнської молоді має постмодерністські елементи, серед яких можна виділити прагнення до самореалізаџї, ігнорування майбутнього, схильність до гедоністичних изіностей. Можливими причинами поширення серед молоді даних тенденцій можуть виступати процееси глобалізації та актуальна мас-медійна культура. Подальші дослідження подібної тематики сприятимуть розв'язанню багатьох молодіжних проблем сьогодні та проблем нашого суспільства в майбутньому.

Ключові слова: життевий світ, інтерпретація, постмодерн, самореалізачія.

Сучасний розвиток українського суспільства характеризують як період трансформаційних процесів, що зумовлений пошуком власного шляху розвитку. Україна як незалежна держава, що не так давно стала на самостійний шлях формування нових соціально-економічних, політичних, духовних орієнтирів, свої ідеї, мрії та сподівання значною

(C) Скляренко К. О., 2020 
мірою пов' язує з молоддю. Визначити когнітивні вектори, якими вона оперує сьогодні і які складають іiі життєвий світ та формують ставлення до навколишнього світу, - важливе завдання для соціології.

Вважається доцільним припустити, що нове покоління молоді має відмінності в структурі життєвого світу, що зумовлені розповсюдженням нових культурницьких тенденцій постмодерністської доби. Нова епоха постмодерну не могла не вплинути на структуру життєвого світу нового покоління молоді. Відкритим залишається питання щодо якісної специфіки конституюючих елементів життєвого світу сучасної української молоді, тобто цінності якого характеру мають домінування: модерністські чи постмодерністські? Mema cmammi визначення особливостей інтерпретацій життєвого світу сучасної української молоді на прикладі конкретного емпіричного дослідження. Для цього вважається за необхідне відмежувати повсякденність постмодерну від характерної модернової інтерпретації світу за допомогою виділених А. Шюцем ознак когнітивного стилю життєвого світу [3, с. 131]. У своїй роботі ми використовували розуміння життєвого світу А. Шюца, який розглядає життєвий світ як багатошарову мережу інтерсуб'єктивних стосунків, в якій кожна область життєвих сенсів характеризується власним когнітивним стилем і особливою формою релевантності. Він виділяє шість конституюючих елементів життєвого світу: 1) трудова діяльність, орієнтована на зовнішній світ; 2) специфічна упевненість в існуванні і достовірності сприйняття зовнішнього світу; 3) активне і напружене відношення до життя; 4) сприйняття часу через призму трудових ритмів; 5) визначеність особистої самоідентифікації; 6) особлива форма соціальності як світ соціальної дії і комунікації $[3$, с. 133].

Базові цінності особистості формуються в період так званої первинної соціалізації індивіда, до 18-20 років, а потім стають достатньо стабільними, суттєво змінюючись лише у кризові періоди життя людини і їі соціального середовища [2, с. 100]. Саме тому був використаний такий метод дослідження, як глибинне інтерв'ю серед молодих людей віком від 18 до 22 років, тобто тих, хто народився вже в незалежній Україні. У роботі аналіз подано у формі короткого переказу біографічних текстів із виділенням фрагментів, що характеризують навички їхніх авторів осмислювати події власного життя. Фрази й вирази, які допомагають охарактеризувати лексичну специфіку розповідей, підкреслюють характерні життєві стратегії та практики їх реалізації. У реалізації моделей трудової поведінки представники досліджуваного нами покоління не мають своєї специфіки, оскільки повноцінно не представлені на ринку праці - більшість ще продовжує навчання, і лише деякі 3 них самостійно заробляють собі на життя, здебільшого поєднуючи роботу та навчання. Тому ми можемо говорити в даному випадку про бажані моделі трудової поведінки, тобто те, як уявляється трудова діяльність для багатьох із них та до чого вони 
прагнуть під час іiі реалізації. Модерн відкриває раціоналізм та активізм, прогрес науки і техніки, зростання професіоналізму. Постмодерн, у свою чергу, наголошує на поліваріативності суспільного розвитку, запереченні прогресу, зниженні ролі професійної трудової діяльності, матеріальному успіху [1, с. 165]. У ході нашого дослідження ми зафіксувати, що робота, кар'єра, матеріальне благополуччя хоч і розглядаються у відповідях наших респондентів як неодмінна складова частина сучасного життя, проте виступають в якості не самостійних досягницьких ідеалів, а як необхідний грунт для більш важливої моральної та професійної самореалізації. Так, можна зафіксувати загальні тенденції, що свідчать про те, що молоде покоління визнає роботу, кар'єру, матеріальне благополуччя важливими: «Я вважаю, щзо в приничипі в молоді иінності й уклад життя змінюються в бік досягнення якихось кар'єрних висот раніше, ніж родини» (Карина, 20 р.). Проте трудову діяльність та кар'єру розглядають не як самоціль та вимушену діяльність, спрямовану на забезпечення фізичного існування індивіда, а як можливість отримання задоволення та фінансового забезпечення: «A гроші - ие вже й можливість мандрувати із друзями, ие $i$ здоров'я батьків, і розвиток та розваги, купа всього» (Артем, 19 років). Для них важливіші їхні інтереси та комфорт: "Але для мене важливо, щсо я займаюся справою, яку люблю, і вірю в те, щзо мені це принесе гарний заробіток. Тому щзо це справа життя. У мене не робота = гроші, а робота = гроші $і$ задоволення від иієї роботи» (Руслан, 22 р.).

Натомість підкреслюють значення самореалізації, не обов'язково у трудовій сфері: «Поки я молодий, у мене є два пріоритети. Це пізнання світу й самовдосконалення, $i$, звісно, моя робота та навчання» (Артем, 19 р.). Це надає змогу побачити, що для багатьох молодих людей праця вже не має соціальної значущості, іiі розглядають, головним чином, як засіб задоволення особистих потреб. Суспільне визнання праці та трудових досягнень для молоді не має сенсу, а провідними є ті цінності, які пов'язані з потребою людини в самореалізації. Молодь позитивно оцінює відносини в сім’ї та спілкування з друзями. Тобто первинне комунікативне середовище (близьке оточення) молоді люди позиціонують як дуже сприятливе: «I звичайно ж, я намагаюся $і$ люблю проводити час зі своӥми друзями та сім'єю, вони для мене дуже важливі й займають далеко не останнє місие в моєму житті» (Денис, 21 р.).

Ставлення молодих людей до праці в цей момент - це сукупний результат попереднього історичного етапу розвитку суспільства в усіх його сферах, у тому числі в економічній. Це свідчення економічної культури суспільства, загальної культури, умова здійснення реформ, запорука можливих змін на краще в майбутньому: «Для багатьох людей багатство й влада більще не є найбільшими иінностями життя. Найголовніше для них - мати ціккаву роботу, любити й бути коханими. На мій погляд, у цььому й полягає щзастя та громадський прогрес» (Ігор, 20 р.). Імовірно, із цим пов'язана оптимістична оцінка 
своєї дозвіллєвої сфери та життя в цілому. Очевидно, такий оптимізм пов'язаний не лише зі специфікою вікової психології, а й зі перебуванням у точці стартової позиції. Висловлювання «погано» переважають тільки в оцінці молодими людьми своєї участі в суспільно-політичному житті. По суті, це «погано» означає фактичну неучасть і індиферентне ставлення до цієї сторони життя. Дійсно, «сім'я», «друзі», «любов», «здоров'я»-яскрава домінанта ціннісних пріоритетів наших респондентів. Потім ідуть цінності професійної та особистої самореалізації й матеріального благополуччя.

Панування модернової довгострокової перспективи замінюється «короткостроковою ментальністю», намаганням жити «одним днем», що сповідується ідеологією гедонізму, нарцисизму та суспільства споживання [1, с. 165]. За умов нестабільного суспільства в сучасного українця знижується здатність керувати власною долею, представники молодого покоління, сприймаючи сучасне українське суспільство як суспільство ризику, максимально рухливе та мінливе, передусім, переймаються пошуком стратегій адаптації до актуального сьогодення: «Бути впевненим у своєму майбутньому й бути украӥнцем - цуе два несумісних поняття, тому шо сьогодні ти працюєш і маєш капітал та статус, а завтра - ні!» (Наталя, 22 р.).

Проте такі тенденції нестабільності соціуму адекватно сприймає сучасне молоде покоління, для яких наявні умови виступили як єдино існуючі та можливі, викликавши своєрідні моделі поведінкової активності. Інноваційний для попередніх поколінь віртуальний мас-медійний світ сучасне молоде покоління сприймає як реально існуючий, а для деяких представників він навіть здається більш реальним, ніж наявний фізичний. Усупереч оптимістичному модерністському «розчаклуванню» світу постмодерн сьогодні знову повертає нас до невизначеності і нестійкості світу до-модерну, в якому провідну роль починає займати світ віртуальної реальності [2, с. 100]. Молоде покоління активно спілкується у віртуальному світі, заводить знайомства, дістає нову інформацію, заробляє гроші тощо. Віртуальний світ вони розглядають як культуру, в межах якої виникли нові засоби для особистісного розвитку, а особливо для тих, кому з якихось причин важко це зробити в наявному фізичному світі. Для молоді зараз існує реальний світ та світ віртуальної реальності. Тобто можемо зробити висновок, що сучасна молодь у своїх моделях поведінки розглядає як поле діяльності не лише фізичний світ, а й віртуальний - як реально існуючий: «Люди дуже багато спілкуються онлайн, $і$ я не виняток» (Карина, 20 р.).

За аналогією із традиційним розподілом життєвого світу на сакральний, за яким визначалась найбільша цінність, та профанний, який цікавий лише як досягнення сакрального, для деяких представників молодого покоління віртуальний світ стає важливішим, ніж реальний: «Для деяких віртуальний образ стає важливішим, ніж у звичайному житті» (Карина, 20 р.). Це є свідченням повної віртуалізації та 
домінування симулякрів. «Картинка, щзо нещзодавно гуляла в Інтернеті: сидить людина, доїдає «Мівіну», при и̧ьому в неї айфон... Хибні иінності виникають» (Денис, 21 р.).

У молодого покоління ми знаходимо дійсно нові моделі поведінки, які мають мало спільного з тими, що можна було спостерігати в homo soveticus. Багато молодих українців, адаптуючись до пострадянського світу, не втілюють норм старших поколінь. Нові умови диктують їм принцип індивідуального виживання, самостворення та самовираження, який і стає основою їхньої нормативної системи: «От чому говорять: «Людина - сама творецьь свого щастя?». Оточення може лише допомогти тобі в досягненні мети, підтримати у важку хвилину, але основну роботу доведеться виконувати самостійно» (Наталя, 22 р.).

Досить часто серед сенсожиттєвих цінностей сучасної молоді респонденти згадували «життя»: «Жити, насолоджуватися кожним днем» (Руслан, 22 р.), «Нерозумно жити марно, витрачати час на непотрібні ні тобі, ні оточенню речі, справи, вчинки» (Артем, 19 р.). Частота подібних висловів дала підстави інтерпретувати цей факт як відображення гедоністичного ситуативного ставлення до світу, за якого саме життя сприймають як гру (тут у широкому значенні - як діяльність, що не має безпосередньо практичної цілі й приносить людині радість сама по собі). Унаслідок докорінних соціальних змін і невизначеності майбутнього раніше значущі і соціально затребувані моделі поведінки не мають структурного підкріплення, підтримки, а довгострокові практичні цілі, стратегії, плани втрачають своє значення. У такій ситуації набуває поширення ігрова модель поведінки, націлена на отримання задоволення від переживання подій самого життя. Звідси поширена думка про те, що «в кожного - свій власний світ, своє життя».

Головний висновок може полягати в такому: в умовах соціокультурної трансформації українського суспільства макросоціальні структури втрачають своє значення в повсякденному житті, внаслідок чого смисловий горизонт сучасної особистості звужується до меж безпосередньої особистої взаємодії, рівня малих соціальних груп. Як уже було зазначено раніше, для моделі трудової поведінки сучасної молоді не характерне активне прагненням до самореалізації в досягненні кар'єрних висот, тому що на перше місце виходить модель поведінки, яка пропагує активність у тій сфері, яку людина суб'єктивно сприймає як можливе джерело самореалізації та самовираження.

Перебіг життя, актуальні соціокультурні умови, глобальні та трансформаційні процеси, що відбуваються в сучасному світі, вимагають особливих гнучких моделей поведінки, які мають наслідувати всі члени соціуму для своєї успішної адаптації та реалізації своїх прагнень: «Жити, як по лінійці, за правилами, значить бути консерватором. Я не з таких, я новатор, я хочу жити сьогодні» (Наталя, 22 р.).

Ураховуючи фактор невизначеності майбутнього, у процесі «самоозадачування» молоді люди схильні ставити життєві плани 3 огляду 
на перебіг власного життя, часто вибираючи критерій самоосвіти як запоруку успішного здійснення планів: «А я знаю точно, щзо головне завдання на сьогодні-це освіта і знання, які я отримую у великій кількості. I на изей момент сенс мого життя - в навчанні» (Ігор, 20 р.).

Проте деякі респонденти розуміють важливість майбутнього, оскільки покладаються на свої сили. Відмову від думок про майбутнє розглядають навіть як виправдання своєї інфантильності та безповідальності: "Якщьо не думати про майбутнє, є ризик залититися з голою п'ятою точкою в якийсь момент ... Тому все має бути в міру, неможливо просто жити сьогоднішнім днем» (Денис, 21 р.). Основною сферою, в якій не прослідковується планування на майбутнє, є трудова діяльність: «Ніхто з моӥх знайомих не планує працювати на одному місиі все життя» (Артем, 19 р.).

Процес індивідуалізації, суб’єктивації, які мали місце в епоху модерну, знижують соціальну залученість особистості, сприяють соціальному відчуженню та самотності [2, с. 97]. Макросоціальні структури втрачають своє значення в повсякденному житті, на перше місце виходить модель поведінки, яка пропагує активність в тій сфері, яка суб'єктивно сприймається людиною в якості можливого джерела самореалізації та самовираження. Тому неабиякої поширеності набуває субкультурна активність та активність у створенні та підтримці міжособистісних контактів. Переважна більшість наявних об'єднань молоді, на які вказується в інтерв'ю, не займалася політикою, не брала участі в суспільно-політичному житті країни. Їх створення і діяльність в основному були спрямовані на задоволення приватних інтересів. Політика не є пріоритетною сферою інтересів сьогоднішньої молоді, інтерес до неї зумовлений переважно отриманням інформації. Серед форм політичної участі поширеними є такі: обговорення політичної ситуації з друзями, участь у передвиборчій кампанії. Тобто ми бачимо, що навіть під час розгляду питань публічної, політичної залученості сучасна молодь враховує, в першу чергу, свої власні, приватні інтереси: «Політика? Мене поки щзо це не хвилює... Це взагалі нагадує зачароване коло, а я хочу займатися собою, а не їх інтригами» (Ігор, 20 р.).

Більшість наявних об’єднань молоді, на які вказано в інтерв'ю, не займалася політикою, не брала участі в суспільно-політичному житті країни. Їх створення і діяльність в основному були спрямовані на задоволення, знову ж таки, приватних інтересів: дозвіллєвих, рекреаційних. Молодіжні об'єднання мають більше субкультурний характер, ніж офіційно-організаційний. Байдуже ставлення загалу молоді до суто молодіжних організацій та об'єднань $є$ свідченням «приватизації» життя переважної частини молоді, тобто «приватного» кола людей за інтересами тощо. Сюди ж можна зарахувати форми соціальної взаємодії. На наш погляд, прикладом цього може виступати широка залученість до різноманітних соціальних мереж, які формуються за принципом «свій-чужий» (входження до списку друзів, 
можливість переглядати закриті для широкого доступу фотоальбоми, залишати коментарі, членство в закритій групі): «Зараз легко мобілізувати людей, наприклад ми знаємо як підписники в Інстраграмі за пару днів збирають мільйонні суми на благодійність, головне -мотивувати людей, тому щчо вони готові підтримувати якусь ідею, якщя їм особисто близька буде ия ідея або їх авторитету» (Карина, 20 р.).

Прояв активності сучасної молоді спостерігається лише в тому випадку, якщо це вважається важливим для самореалізації. Людина та іiі інтереси є найвищою цінністю: «Раніше, на периому курсі, брав участь у громадській діяльності, займався волонтерством, на телебаченні студентському, допомагав в організаиії культурно-масових заходів. Але потім зрозумів, щзо я не хочу, щуоб мені хтось вказував, вирішував, щуо за мене робити, тим більше цее займає величезну кількість часу» (Артем, 19 р.). Активність сучасної молоді розглядають як нову можливість сучасного світу і результат власного, відповідального вибору: «У нас виникла свобода вибору. Ти можеш прожити все життя неодруженим, феміністкою, не заводити ніколи дітей, працювати на фермі і їсти горішки кеш'ю. А можеш у 18 років вийти заміж, народити дітей, у 38 будуть онуки, насолоджуватися життям і працювати бухгалтером» (Денис, 21 р.).

Поєднання індивідуалістичних та соціальних («колективістських») тенденцій особистості виявляється лише у вузьких взаємних соціально-психологічних зв'язках, тобто в таких, які базуються на взаємній підтримці та довірі і створюють «соціальний капітал» індивіда. В Україні цим «капіталом» для молодих людей, як і для більшості населення, виступають тільки рідні, друзі й близькі знайомі. Блок питань дослідження торкався конституювання комунікативного кола: хто «свій» і хто «чужак». 3'ясувалося, що найбільш значущим для респондентів є виключно «малий» комунікативний круг: батьки, друзі, знайомі, кохана людина. Водночас у горизонті їхнього досвіду відсутні цінності служіння суспільству, «людям» та й до громадського та політичного життя молодь цілком індиферентна.

Індивідуалізація стилю життя сприяє розвитку таких якостей, як егоїзм, апатія, цинізм, але одночасно стимулює молодь виявляти ініціативу, боротися за виживання в нових умовах. Молодь орієнтована на радикальні зміни в економіці, віддає перевагу ринковій економіці, яка активно формує нову психологію споживання й нове економічне мислення. Соціальні успіхи та досягнення зумовлюють розвиток у молоді більш реалістичного, цілісного осмислення власного життевого шляху, що сприяє здатності краще будувати власні майбутні плани, зокрема матеріального та духовного вдосконалення.

Як бачимо, сучасна українська реальність зазнає неабиякої рефлексивності з боку молодих українців. У молодого покоління ми знаходимо дійсно нові моделі поведінки, які мають мало спільного 3 тими, які можна було спостерігати в homo soveticus i які багато в чому 
відрізняються від модернового нормативу (це не означає, звісно, що всі люди цього віку виступають їх носіями або що вони взагалі відсутні в старших поколінь). Ми вважаємо, що існує тип молодого українця, для якого характерний високий рівень автономії щодо соціуму й соціальних інститутів. На відміну від радянського індивіда, він не апелює до суспільства та його норм; примушений рахуватися 3 ними, він протиставляє їм свої власні правила. Усе соціальне, інституціональне, «узагальнений інший» видаються йому зовнішнім середовищем, індиферентним, а то й ворожим. Його кінцева мета - незалежність, особисті інтереси, носії такого типу вважають, що вже годі розраховувати на інших, треба діяти самим, вони вірять у себе, свою індивідуальність. Такі молоді люди пройшли процес соціалізації після руйнування радянської інституційної системи. Нові умови диктують їм принцип індивідуального виживання, самостворення та самовираження, який і стає основою їхньої нормативної системи.

Головний висновок може полягати в такому: в умовах соціокультурної трансформації українського суспільства макросоціальні структури втрачають своє значення в повсякденному житті, унаслідок чого смисловий горизонт сучасної особистості звужується до меж безпосередньої особистої взаємодії, рівня малих соціальних груп. Для такої моделі активного сприйняття життя деякою мірою є характерним використання постмодерністських технік життєздійснення. Як уже було зазначено раніше, для моделі трудової поведінки сучасної молоді не характерне активне прагнення до самореалізації в досягненні кар'єрних висот, тому що на перше місце виходить модель поведінки, яка пропагує активність у тій сфері, яку людина суб'єктивно сприймає як можливе джерело самореалізації та самовираження. Неабиякої поширеності набувають субкультурна активність та активність у створенні й підтриманні міжособистісних контактів.

Ми можемо зробити висновок, що молоде покоління демонструє відмінні від попередніх поколінь дискурсивні стратегії організації повсякденності. Саме молодь своїми поведінковими моделями схильна демонструвати прояви постмодерністських цінностей у соціокультурному українському просторі. Проте такі висновки не дають підстав говорити про остаточне утвердження постмодернізму в українському суспільстві. Можливими причинами поширення серед молоді даних тенденцій можуть виступати процеси глобалізації та актуальна мас-медійна культура. Адже сучасні українські ЗМІ транслюють типові західні моделі поведінки, які наповнені ідеями постмодернізму. Культура молодих сучасників формується в умовах трансформації сучасного українського суспільства та переосмислення духовних цінностей, норм, ідеалів та ідей, що становлять основу визначення пріоритетних напрямів розвитку держави, в тому числі і на формування та становлення демократичних ціннісних засад. Цей процес супроводжується розчаруванням у попередній системі ціннісних 
орієнтацій, втратою і зневірою в ідеалах та цінностях, а також відсутністю нової ієрархії ціннісних орієнтацій через страх перед невідомим, майбутнім та апатією. У таких умовах молодь більше тяжіє до формування нової системи цінностей, ніж до підтримки старої. Дані тенденції ще раз наголошують на можливості розглядання сучасної молоді в якості носіїв певних засад постмодерністської свідомості в Україні, серед яких можна виділити прагнення до самореалізації, актуальність сьогодення та ігнорування майбутнього, схильність до наслідування гедоністичних цінностей. Подальші дослідження подібної проблематики сприятимуть розв'язанню багатьох молодіжних проблем сьогодні та проблем нашого суспільства в майбутньому.

\section{Список використаної літератури}

1. Борисова Ю.В. Субьект в ситуации постмодерна. Постмодерн: новая магическая эпоха: сборник статей / Под ред. Л.Г. Ионина. Харьков, 2002. С. 164-167.

2. Гаврилюк В.В., Трикоз Н.А. Динамика ценностных ориентаций в период социальной трансформации (поколенный подход). Социологические исследования. 2002. № 1. С. $96-105$.

3. Шюц А. Структура повседневного мышления. Социологические исследования. 1988. № 2. С. 130-136.

\footnotetext{
Скляренко Е. А. Жизненный мир современной молодежи в актуальных украинских реалиях

В статье рассматриваются особенности интерпретаций жизненного миранапримереисследованийсовременнойукраинскоймолодежи. Выдвигается тезис о наличии постмодернистских тенденций в ее ориентациях. Мы можем зафиксировать общие тенденщии, которые указывают на то, что молодое поколение не считает профессиональный успех главным приоритетом в жизни. Отношения с семьей, любимым человеком, половая сфера и общение с друзьями позитивно очениваются молодежью. "Семья», «друзья», «любовь», «здоровье» - это яркие доминирующие иченности иенностных приоритетов наших респондентов. Затем следуют профессиональная u личная самореализация и материальное благополучие. Современная молодежь рассматривает виртуальный мир как реальный, где активно общаются, знакомятся, получают новую информацию, зарабатьвают деньги.

В условиях социокультурной трансформации украинского общества макросочиальные структуры утрачивают свое значение в повседневной жизни. Поэтому субкультурная деятельность и межличностные контакть распространяются среди современной молодежи. Существует также ориентация на сочииальную пассивность и неактивное участие в общественной жсизни.

Новые реалии диктуют приничип индивидуального выживания, самореализации, который становится основой новой нормативной системы. В Украине только родственники, друзья и близкие знакомые выступают в роли «социального капитала» для молодежи. Молодежь безразлична $\kappa$ молодежным организациям и объединениям. Это свидетельствует o «приватизации» жизни, пренебрежении $\kappa$ сочиальным проблемам, неспособности конструктивно выражать себя и свои потребности.
} 
На основе данных эмпирического исследования делается вывод о том, что мир современной украинской молодежи имеет постмодернистские элементы, среди которых можно выделить: стремление к самореализации, игнорирование будущего, склонность к гедонистическим иенностям. Возможными причинами распространения среди молодежи данных тендениий могут выступать прочессы глобализачии и актуальная масс-медийная культура. Дальнейшие исследования данной тематики будут способствовать решению многих молодежных проблем сегодня и проблем нашего общества в будущем.

Ключевые слова: жизненный мир, интерпретация, постмодерн, самореализачия.

\section{Skliarenko K. Life world of modern youth in actual Ukrainian realities}

In the article the features of interpretations of the vital world are examined on the example of researches of modern Ukrainian youth. A thesis is pulled out about the presence of nостмодерністських tendencies in her orientations. We can capture general trends that indicate that the younger generation does not consider professional success a top priority in life. The relationship between the family, the loved one, the sexual sphere and communication with friends are positively evaluated by the youth. "Family", "friends", "love", "health" are the bright dominant values of our respondents' value priorities. Then follow the values of professional and personal self-realization and material well-being. The modern youth views the virtual world as real, where it actively communicates, makes acquaintances, obtains new information, makes money.

In the conditions of socio-cultural transformation of Ukrainian society, macrosocial structures lose their importance in everyday life. Therefore, subcultural activity and interpersonal contacts are spreading among modern youth. There is also an orientation towards social passivity and low participation in public and public life.

New realities dictate the principle of individual survival, self-realization, which becomes the basis of the new normative system. New realities dictate the principle of individual survival, self-realization, which becomes the basis of the new normative system. In Ukraine, only relatives, friends and close acquaintances act as "social capital" for young people. Youth are indifferent to youth organizations and associations. It testifies to the "privatization" of life, the neglect of social problems, the inability to express oneself and their needs in constructive ways. Based on empirical research, it is concluded that the lifeworld of contemporary Ukrainian youth has postmodern elements. Among which are the desire for self-realization, the neglect of the future, the tendency to hedonistic values. Possible reasons for the spread of these trends among young people may be the processes of globalization and the current media culture.

Key words: the vital world, interpretation, postmodern, self-realization. 